\title{
Development of matrix controlled transdermal delivery systems of pentazocine: In vitrolin vivo performance
}

\author{
PRIYA RANJAN PRASAD VERMA* \\ ASHOK R. CHANDAK \\ Department of Pharmaceutical Sciences \\ Birla Institute of Technology \\ Mesra, Ranchi-835215, India
}

\begin{abstract}
The present study aimed to develop hydroxypropyl methylcellulose based transdermal delivery of pentazocine. In formulations containing lower proportions of polymer, the drug released followed the Higuchi kinetics while, with an increase in polymer content, it followed the zero-order release kinetics. Release exponent $(n)$ values imply that the release of pentazocine from matrices was non-Fickian. FT-IR, DSC and XRD studies indicated no interaction between drug and polymer.

The in vitro dissolution rate constant, dissolution half-life and pharmacokinetic parameters $\left(C_{\max }, t_{\max }, A U C_{(\mathrm{s})}, t_{1 / 2}\right.$, $K_{\mathrm{el}}$, and $M R T$ ) were evaluated statistically by two-way ANOVA. A significant difference was observed between but not within the tested products. Statistically, a good correlation was found between per cent of drug absorbed from patches vs. $C_{\max }$ and $A U C_{(\mathrm{s})}$. A good correlation was also observed when per cent drug released was correlated with the blood drug concentration obtained at the same time point. The results of this study indicate that the polymeric matrix films of pentazocine hold potential for transdermal drug delivery.

Keywords: pentazocine, transdermal drug delivery, Cygnus' sandwich patch holder, in vitro characterization, in vivo evaluation
\end{abstract}

Transdermal drug delivery system is being extensively investigated as a viable alternative to drug delivery with improved bioavailability. It offers many advantages over conventional administration such as enhanced efficacy, increased safety, and greater convenience and improved patient compliance. Transdermal route permits the use of a relatively potent drug with minimal risk of systemic toxicity and avoids gastrointestinal degradation and hepatic first-pass metabolism (1-3). A number of therapeutic agents, including antihypertensive, antianginal, antihistaminic, anti-inflammatory, analgesic,

\footnotetext{
* Correspondence; e-mail: prpverma275730@yahoo.com
} 
P. R. P. Verma and A. R. Chandak: Development of matrix controlled transdermal delivery systems of pentazocine: In vitro/in vivo performance, Acta Pharm. 59 (2009) 171-186.

and anti-arthritic drugs, are being investigated and developed for the transdermal therapeutic system either for academic research or for commercial purposes $(3,4)$. The present work is aimed at developing a matrix-dispersion type transdermal drug delivery of pentazocine.

Pentazocine (PTZ), a benzomorphan derivative, is an opioid analgesic that has mixed opioid agonist and antagonist actions. It is considered to be a partial agonist or weak antagonist at the $\mu$-receptor and a $\kappa$-receptor agonist. Pentazocine is used for relief of moderate to severe pain. Oral administration of PTZ has the disadvantage of low bioavailability (about 18-22 \%) due to extensive first-pass metabolism (5-7). In addition, PTZ has a short half-life of $2-4 \mathrm{~h}$ and requires frequent dosing in order to maintain the optimal therapeutic concentration. Repeated injections over long periods may cause fibrotic changes in the skin and muscular tissue. Low molecular mass (285.4), suitable $\mathrm{pK}_{\mathrm{a}}$ values of 8.5 and $10, \log P$ (octanol/phosphate buffer $\left.\mathrm{pH} 7.4\right)$ of 2.0 and low oral bioavailability provide a rationale for developing a transdermal delivery system of PTZ. Polymers play an important role in designing such delivery systems (8). Varying grades and ratios of rate controlling polymers, hydroxypropyl methylcellulose (HPMC K4M, HPMC K15M and HPMC K100M) together with a plasticizer (glycerin) were used in the design and development of a matrix dispersion type transdermal delivery of pentazocine.

\section{EXPERIMENTAL}

\section{Materials}

Pentazocine was a gift from Ranbaxy Research Laboratory, India. Hydroxypropyl methycelluloses (HPMC) K4M, K15M and K100M were gifts from Colorcon Ltd., UK. ScotchPak ${ }^{\mathrm{TM}} 1022$ release liner and ScotchPak ${ }^{\mathrm{TM}} 1109$ backing membrane were obtained from 3M Drug Delivery Systems, USA. Other solvents and reagents used were of analytical grade.

\section{Preparation and characterization of pentazocine transdermal films}

Matrix type transdermal patches containing PTZ were prepared using various concentrations of HPMC K4M, K15M and $\mathrm{K} 100 \mathrm{M}$, keeping the drug concentration constant (10 mg per $2.25 \mathrm{~cm}^{2}$ patch). The drug to polymer mass ratios were 1:1, 1:1.5, 1:2, 1:2.5, 1:3 and 1:3.5. The required amounts of drug and polymer were dispersed separately in casting solvent (acetone/distilled water, 9:1). The polymeric dispersion was sonicated for 2 min to remove entrapped air bubbles. The two were then mixed and glycerin $(150 \%$, $\mathrm{m} / \mathrm{m}$, of polymer mass) was incorporated as plasticizer. The polymeric dispersion of the drug was poured into a glass mould $(6 \times 6 \mathrm{~cm})$ fabricated in the laboratory. To control the rate of solvent evaporation, the mould was covered with a funnel of suitable size. Casting solvent was then allowed to evaporate overnight to obtain dry films. Films were cut into small patches containing an equivalent of $10 \mathrm{mg}$ of the drug per patch. Backing membrane was glued and patches were stored between sheets of wax paper in a desiccator. 
P. R. P. Verma and A. R. Chandak: Development of matrix controlled transdermal delivery systems of pentazocine: In vitro/in vivo performance, Acta Pharm. 59 (2009) 171-186.

Thickness. - The thickness of the films was assessed using an electronic digital instrument (FT-1000, Spectralab, India). The film was placed on an iron surface and the probe was placed on the film surface. The apparatus was calibrated with a calibration film of $103 \pm 3 \mu \mathrm{m}$ (Spectralab, India). Ten randomly selected patches of each formulation were tested for thickness. The thickness was measured at 5 separate points of each patch in order to ensure uniform thickness.

Mass variation. - The patches were tested for mass variation by individually weighing ten randomly selected patches.

Film folding endurance. - This was determined by repeatedly folding the patches at the same place until a crack or break showed. The number of times the film could be folded without breaking/cracking gave the value of folding endurance. Five randomly selected patches of each formulation were tested.

Flatness. - Longitudinal strips from the 5 randomly selected medicated films of each formulation were cut out. The length of each strip was measured, and variations in length due to non-uniformity of flatness were measured. Flatness was calculated by measuring the constriction of strips. $0 \%$ constriction was considered to be $100 \%$ flatness.

Content uniformity. - Ten randomly selected medicated patches were assayed. The patches were dissolved in $2 \mathrm{~mL}$ of the casting solvent and the volume was adjusted to $100 \mathrm{~mL}$ with $0.1 \mathrm{~mol} \mathrm{~L}^{-1} \mathrm{HCl}$. The solution was filtered, suitably diluted and the content per film was estimated spectrophotometrically (UV-1700 PharmaSpec, Shimadzu, Japan) at $278.2 \mathrm{~nm}$.

\section{Fourier transform infrared spectroscopic studies (FTIR)}

A IR Prestige-21 FTIR (Shimadzu, Japan) spectrometer equipped with an attenuated total reflectance (ATR) accessory was used to obtain infrared spectra of the drug matrix as well as placebo films. FTIR analysis of pentazocine, pure polymers and their physical mixtures $(1: 1, m / m)$ was carried out using diffuse reflectance spectroscopy (DRS)-FTIR with $\mathrm{KBr}$. All powder samples were dried under vacuum prior to obtaining any spectra in order to remove the influence of residual moisture. For each spectrum, 32 scans were obtained at a resolution of $4 \mathrm{~cm}^{-1}$ from $4000-600 \mathrm{~cm}^{-1}$.

\section{Differential scanning calorimetric studies (DSC)}

Thermal analysis was carried out using a differential scanning calorimeter (Q10, TA Instruments, Waters Inc., USA) with a liquid nitrogen cooling accessory. The analysis was performed under purge of dry nitrogen gas $\left(50 \mathrm{~mL} \mathrm{~min}^{-1}\right)$. High purity indium was used to calibrate the heat flow and heat capacity of the instrument. Sample (2.5-5 mg), placed in an aluminum crucible cell was firmly crimped with the lid to provide an adequate seal. The samples were heated from ambient temperature to $250{ }^{\circ} \mathrm{C}$ at a pre-programmed heating rate of $10{ }^{\circ} \mathrm{C} \mathrm{min}-1$. All samples were analyzed in the same manner. In the case of two component systems, physical mixtures of individual compounds (all passed through $0.15-\mathrm{mm}$ sieve) in equal mass ratios were prepared using a glass pestle and mortar. 
P. R. P. Verma and A. R. Chandak: Development of matrix controlled transdermal delivery systems of pentazocine: In vitro/in vivo performance, Acta Pharm. 59 (2009) 171-186.

\section{$X$-ray diffraction studies (XRD)}

X-ray diffraction (XRD) patterns of pure drug, placebo films and drug loaded matrix films were obtained using a Rigaku-Miniflex (Japan) diffractometer. Measurement conditions consisted of a target $\mathrm{Cu}-\mathrm{K} \alpha$ radiation anode, voltage $30 \mathrm{kV}$ and current 15 $\mathrm{mA}$. Diffraction patterns were obtained using a step width of $0.02^{\circ} 2 \theta$ between $2^{\circ}$ and $60^{\circ} 2 \theta$ at a rate of $2^{\circ} \mathrm{min}^{-1}$ at ambient temperature.

\section{In vitro dissolution studies}

The in vitro dissolution study of each selected transdermal patch was performed using a USP 25 (9) type 5 dissolution test apparatus equipped with a fractional collector (TDT-08L, Electrolab, India). A Cygnus' sandwich patch holder, a slightly modified form of FDA's sandwich patch holder was used to ensure patch-to-patch reproducibility of transdermal films (10-12). The dissolution vessel contained $500 \mathrm{~mL}$ of phosphate buffer (pH 6.6) maintained at $32 \pm 0.5^{\circ} \mathrm{C}$ (the skin surface temperature) and paddle speed was set at $50 \mathrm{rpm}$. Patch assembly was carefully placed at the bottom of the vessel and was centered using a glass rod. Five $\mathrm{mL}$ samples were withdrawn at one hour intervals until completion of drug release. The withdrawn sample was replenished with $5 \mathrm{~mL}$ of fresh medium.

The withdrawn samples were analyzed spectrophotometrically (UV-1700 PharmaSpec, Shimadzu, Japan) at $278.2 \mathrm{~nm}$ (6). Three determinations were carried out for each formulation. The content of pentazocine was calculated from the standard curve. The in vitro dissolution profiles, namely, cumulative drug release, dissolution rate constant $\left(r_{0}\right.$, $r_{1}$ and $\left.r_{\mathrm{H}}\right)$ and dissolution half-life $\left(t_{50}\right)$ were calculated.

\section{Skin irritation and in vivo studies in rabbits}

The formulations were tested for skin irritation and bioavailability on nine healthy rabbits of either sex weighing $1.917 \pm 0.098 \mathrm{~kg}$ following the balanced incomplete block design. The protocol for the study on rabbits was approved by the Institutional Animal Ethical Committee (Birla Institute of Technology, Mesra, Ranchi, India). The hair of a skin area of around $5.0 \mathrm{~cm}^{2}$ was shaved, covering both sides of the vertebral column of each rabbit and care was taken to avoid skin damage during shaving. The formulation was applied onto the shaved surface 24 hours after hair removal. The patch was placed over the skin with the help of surgical adhesive tape. Blood samples were collected from the ear vein prior to application of films and then at 1, 2, 4, 6, 8, and $24 \mathrm{~h}$ post application. Due to the small size of the animal and damage to the ear vein, it was not advisable to withdraw more blood than at the aforementioned intervals. The withdrawn blood samples were stored in well closed tubes under refrigeration $\left(-20^{\circ} \mathrm{C}\right)$ until further analysis.

PTZ was estimated in whole blood using the previously reported spectrofluorometric method with some modifications (13). The diluted blood sample (2 mL) was mixed with a $100 \mathrm{mg}$ mixture of sodium carbonate/sodium hydrogencarbonate (1:1) and shaken with $4 \mathrm{~mL}$ of benzene for $10 \mathrm{~min}$. Next, a 3-mL portion of the organic phase was separated by centrifugation at $5000 \mathrm{rpm}$ and transferred into fresh tubes and further shaken with $3 \mathrm{~mL}$ of $0.2 \mathrm{~mol} \mathrm{~L}^{-1} \mathrm{HCl}$, which was previously saturated with benzene, for 
P. R. P. Verma and A. R. Chandak: Development of matrix controlled transdermal delivery systems of pentazocine: In vitro/in vivo performance, Acta Pharm. 59 (2009) 171-186.

$10 \mathrm{~min}$. After centrifugation, the aqueous layer was separated and its fluorescence intensity was measured on a spectrofluorometer (RF 5301 PC, Shimadzu) equipped with RF-530XPC computer software. The samples were measured at excitation wavelength of $280 \mathrm{~nm}$ and emission wavelength of $311 \mathrm{~nm}$, in a 10-mm quartz cell at ambient temperature. The pharmacokinetic parameters were calculated using non-compartmental pharmacokinetic data analysis software, WinNonlin version 5.0.1

\section{Data analysis and statistics}

The relevance of differences in the in vitro dissolution rate profile and pharmacokinetic parameters were evaluated statistically. The data were tested by the two-way analysis of variance.

\section{RESULTS AND DISCUSSION}

Matrix dispersion type transdermal films of pentazocine were prepared using different grades of HPMC as rate controlling polymers. To get suitable matrices for transdermal films, various drug to polymer mass ratios were applied. The formulations made were evaluated for their physicochemical, in vitro and in vivo performance. Thickness, mass variation, and drug content of the formulations are shown in Table I. Thickness and mass of the patch increased with the increase in polymer content and its viscosity grade (HPMC K4M, K15M and $\mathrm{K} 100 \mathrm{M}$ ). Irrespective of the grade and concentration of HPMC used, the drug content was found within $9.932 \pm 0.007$ and $9.986 \pm 0.008 \mathrm{mg}$ per patch with an RSD of $0.1 \%$ indicating uniform distribution of the drug in matrix films.

The flatness study results showed that none of the formulations had different strip lengths before and after longitudinal cut, indicating $100 \%$ flatness, and thus they could maintain a smooth surface when applied onto the skin. The folding endurance values were found to increase with an increase in the viscosity grade and content of the HPMC polymer. The endurance values of matrix films were found within 250-300, indicating good strength and elasticity, which is explained by the linear nature of the cellulose structure.

\section{Drug-polymer interaction studies}

To investigate the possible interactions between PTZ and polymeric materials of the patches, FTIR, DSC and XRD analyses were carried out on pure substances, physical mixtures, placebo polymeric films and PTZ loaded transdermal films.

\section{FTIR}

The DRS-FTIR spectrum of drug/polymer physical mixture was compared with individual spectra of HPMC K15M and pure PTZ (Fig. 1). The DRS-FTIR spectral analysis of pure PTZ showed major peaks at about 1608, 1263, 1238, 1066, and $854 \mathrm{~cm}^{-1}$, confirming the purity of the drug as per established standards (14). The DRS-FTIR analysis of the PTZ/HPMC K15M physical mixture (1:1), showed major peaks corresponding to 
P. R. P. Verma and A. R. Chandak: Development of matrix controlled transdermal delivery systems of pentazocine: In vitro/in vivo performance, Acta Pharm. 59 (2009) 171-186.

PTZ. It can be inferred that there is no interaction between the drug and polymer in a physical mixture.

Table I. Physical characteristics of pentazocine transdermal films

\begin{tabular}{|c|c|c|c|}
\hline Composition $(m / m)$ & Thickness $(\mu \mathrm{m})$ & Mass (mg) & Drug content (mg per $2.25 \mathrm{~cm}^{2} /$ patch) \\
\hline \multicolumn{4}{|l|}{ PTZ:K4M } \\
\hline $1: 1.0$ & $\begin{array}{l}169.70 \\
(1.159)\end{array}$ & $\begin{array}{l}41.858 \\
(0.127)\end{array}$ & $\begin{array}{c}9.976 \\
(0.010)\end{array}$ \\
\hline 1:1.5 & $\begin{array}{l}217.10 \\
(0.876)\end{array}$ & $\begin{array}{l}49.953 \\
(0.133)\end{array}$ & $\begin{array}{c}9.967 \\
(0.014)\end{array}$ \\
\hline $1: 2.0$ & $\begin{array}{l}261.31 \\
(0.866)\end{array}$ & $\begin{array}{l}55.361 \\
(0.187)\end{array}$ & $\begin{array}{c}9.986 \\
(0.008)\end{array}$ \\
\hline $1: 2.5$ & $\begin{array}{l}291.21 \\
(0.833)\end{array}$ & $\begin{array}{l}62.226 \\
(0.156)\end{array}$ & $\begin{array}{c}9.979 \\
(0.017)\end{array}$ \\
\hline $1: 3.0$ & $\begin{array}{l}339.50 \\
(1.020)\end{array}$ & $\begin{array}{l}78.955 \\
(0.135)\end{array}$ & $\begin{array}{c}9.951 \\
(0.011)\end{array}$ \\
\hline 1:3.5 & $\begin{array}{l}379.20 \\
(0.876)\end{array}$ & $\begin{array}{l}88.933 \\
(0.242)\end{array}$ & $\begin{array}{c}9.964 \\
(0.009)\end{array}$ \\
\hline \multicolumn{4}{|l|}{ PTZ:K15M } \\
\hline $1: 1.0$ & $\begin{array}{l}179.20 \\
(1.033)\end{array}$ & $\begin{array}{l}44.461 \\
(0.135)\end{array}$ & $\begin{array}{c}9.968 \\
(0.011)\end{array}$ \\
\hline $1: 1.5$ & $\begin{array}{l}225.80 \\
(0.919)\end{array}$ & $\begin{array}{l}51.073 \\
(0.200)\end{array}$ & $\begin{array}{c}9.932 \\
(0.007)\end{array}$ \\
\hline $1: 2.0$ & $\begin{array}{l}271.90 \\
(0.875)\end{array}$ & $\begin{array}{l}61.995 \\
(0.153)\end{array}$ & $\begin{array}{c}9.971 \\
(0.009)\end{array}$ \\
\hline 1:2.5 & $\begin{array}{l}297.00 \\
(0.816)\end{array}$ & $\begin{array}{l}70.963 \\
(0.107)\end{array}$ & $\begin{array}{c}9.969 \\
(0.008)\end{array}$ \\
\hline $1: 3.0$ & $\begin{array}{l}353.00 \\
(0.943)\end{array}$ & $\begin{array}{l}84.516 \\
(0.087)\end{array}$ & $\begin{array}{c}9.941 \\
(0.006)\end{array}$ \\
\hline 1:3.5 & $\begin{array}{l}399.41 \\
(0.994)\end{array}$ & $\begin{array}{l}98.012 \\
(0.166)\end{array}$ & $\begin{array}{c}9.963 \\
(0.009)\end{array}$ \\
\hline \multicolumn{4}{|l|}{ PTZ:K100M } \\
\hline $1: 1.0$ & $\begin{array}{l}189.50 \\
(1.080)\end{array}$ & $\begin{array}{l}52.124 \\
(0.220)\end{array}$ & $\begin{array}{c}9.981 \\
(0.011)\end{array}$ \\
\hline $1: 1.5$ & $\begin{array}{l}245.80 \\
(0.789)\end{array}$ & $\begin{array}{l}59.951 \\
(0.158)\end{array}$ & $\begin{array}{c}9.982 \\
(0.010)\end{array}$ \\
\hline $1: 2.0$ & $\begin{array}{l}293.90 \\
(0.738)\end{array}$ & $\begin{array}{l}80.963 \\
(0.217)\end{array}$ & $\begin{array}{c}9.965 \\
(0.007)\end{array}$ \\
\hline $1: 2.5$ & $\begin{array}{l}359.89 \\
(0.782)\end{array}$ & $\begin{array}{l}91.297 \\
(0.197)\end{array}$ & $\begin{array}{c}9.934 \\
(0.008)\end{array}$ \\
\hline 1:3.0 & $\begin{array}{l}404.10 \\
(0.876)\end{array}$ & $\begin{array}{c}105.873 \\
(0.142)\end{array}$ & $\begin{array}{c}9.982 \\
(0.016)\end{array}$ \\
\hline 1:3.5 & $\begin{array}{l}428.81 \\
(0.789)\end{array}$ & $\begin{array}{c}118.271 \\
(0.195)\end{array}$ & $\begin{array}{c}9.942 \\
(0.008)\end{array}$ \\
\hline
\end{tabular}

Mean and standard deviation (in parentheses) of 10 readings. 
P. R. P. Verma and A. R. Chandak: Development of matrix controlled transdermal delivery systems of pentazocine: In vitro/in vivo performance, Acta Pharm. 59 (2009) 171-186.

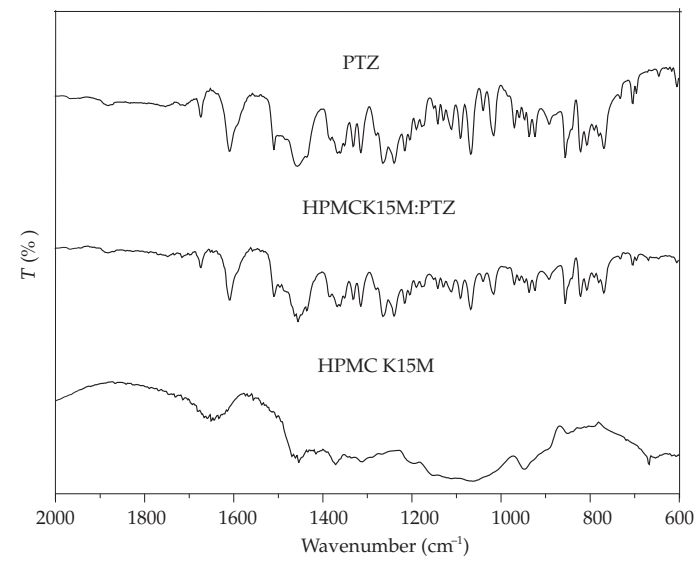

Fig. 1. DRS-FTIR spectra of pentazocine, physical mixture with HPMC K15M (1:1) and pure HPMC K15M.

ATR is a fast and non-destructive sampling technique for obtaining the IR spectrum of the material surface. This technique required minimum, or no, sample preparation, but an intimate optimal contact between the sample and the ATR crystal was crucial (15). ATR-FTIR spectra of PTZ loaded matrix films prepared from HPMC (1:1) were compared with the individual spectra of HPMC placebo films and pure PTZ (Fig. 2). ATR-FTIR spectra gave HPMC characteristic peaks at about 1643, 1109 and $1033 \mathrm{~cm}^{-1}$ of the vibration region in placebo films. Characteristic peaks that corresponded to HPMC and PTZ were retained in drug loaded matrix films, though the intensity of peaks corresponding to PTZ was low. No new peak was found in drug loaded matrix films, which indicates that no interaction between the drug and polymer took place.

\section{DSC}

The DSC thermograms of the pure drug, pure polymer (HPMC K4M, K15M, and $\mathrm{K} 100 \mathrm{M})$ and their physical mixtures (1:1) are shown in Fig. 3. A sharp endothermic peak

Fig. 2. ATR-FTIR spectra of pure pentazocine, placebo film of HPMC K15M and matrix films of PTZ:HPMC (K4M, $\mathrm{K} 15 \mathrm{M}$ and $\mathrm{K} 100 \mathrm{M})$ in 1:1 ratio.

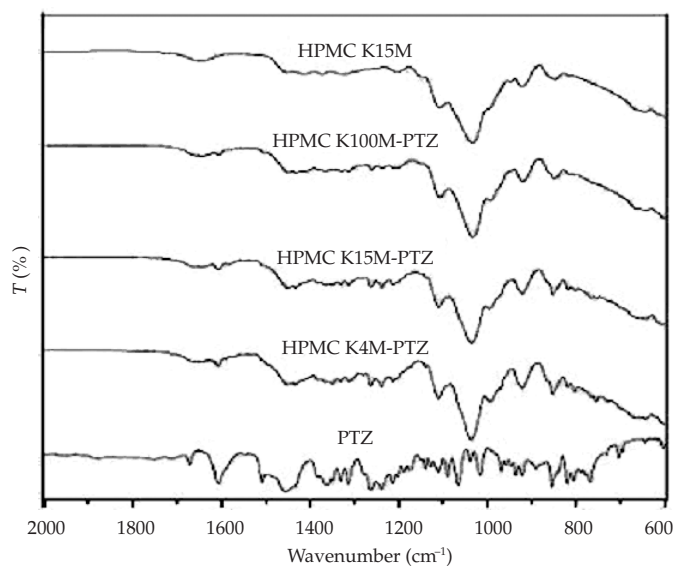


P. R. P. Verma and A. R. Chandak: Development of matrix controlled transdermal delivery systems of pentazocine: In vitro/in vivo performance, Acta Pharm. 59 (2009) 171-186.

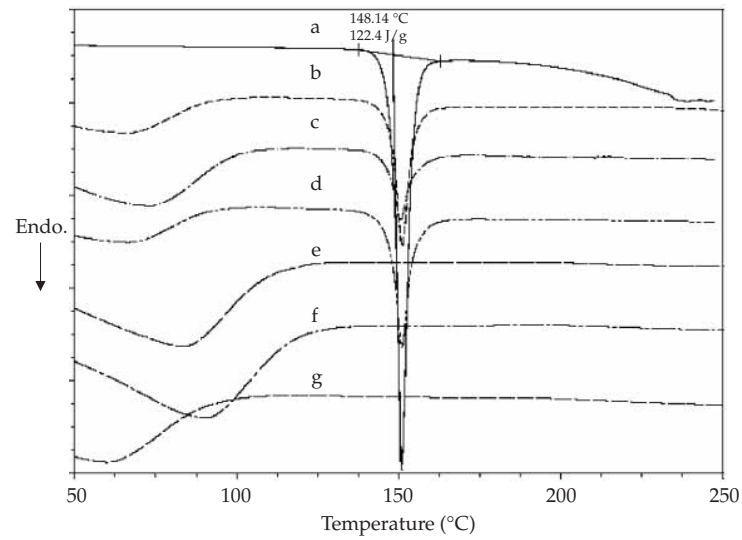

Fig. 3. DSC thermograms of: a) pure pentazocine; physical mixture at 1:1 ratio of pentazocine with $b$ ) HPMC K4M, c) HPMC K15M and d) HPMC K100M, e) HPMC K4M, f) HPMC K15M and g) HPMC K100M.

appeared at $150.93^{\circ} \mathrm{C}$, which corresponds to the drug melting point $(14,16)$. The appearance of the sharp endothermic peak is due to its crystalline nature. In all grades of polymers, a broad endothermic peak, due to the dehydration process, was observed over a temperature range of $60-120^{\circ} \mathrm{C}$. In the physical mixture, the dehydration process peak shifts to a lower temperature range $\left(40-90^{\circ} \mathrm{C}\right)$ (Figs. 3b, 3c, 3d). This may be due to the possible formation of a loose polymer network. Further, the drug melting signal was clearly distinguishable in binary mixtures. On the other hand, pure HPMC did not show any peak in this region. Since no other endothermic event was observed, one can conclude that there was no interaction between the drug and polymer used. This study also indicates that the polymeric grades used are well suited for formulating matrix type patches because of their compatibility with the drugs $(11,17)$.

\section{$X R D$}

The X-ray diffraction patterns of pure drug, placebo films and drug loaded films are shown in Fig. 4. In matrix films, the drug and the polymer were used in the ratio of 1:2. The X-ray diffractogram illustrates the crystalline nature of the drug. Numerous distinctive sharp peaks occurred for PTZ at approximately $2 \theta$ angles of $27,36,39$ and 45 degrees. Placebo films made up of different HPMC grades, exhibited just one broad peak with low intensity at $10-35^{\circ} 2 \theta$ (Fig. 4), which indicates the almost amorphous state of these polymers. Drug-loaded matrix films also demonstrate a nature of diffractogram similar to placebo HPMC films, with lessened intensity. This may be due to the solubility of drug in the polymeric matrix films. The absence of crystalline peaks corresponding to PTZ in matrix films indicates that the drug was molecularly dispersed in matrix films. These results are in accordance with the findings reported earlier (18).

\section{In vitro dissolution studies}

In this study, the effect of various polymeric grades of HPMC on the release behavior and kinetics of PTZ from transdermal films was evaluated. In order to describe the kinetics of drug release from transdermal films, various mathematical models have been 
Fig. 4. XRD spectra of pentazocine, placebo HPMC (K4M, $\mathrm{K} 15 \mathrm{M}$, and $\mathrm{K} 100 \mathrm{M})$ films and drug loaded transdermal films.

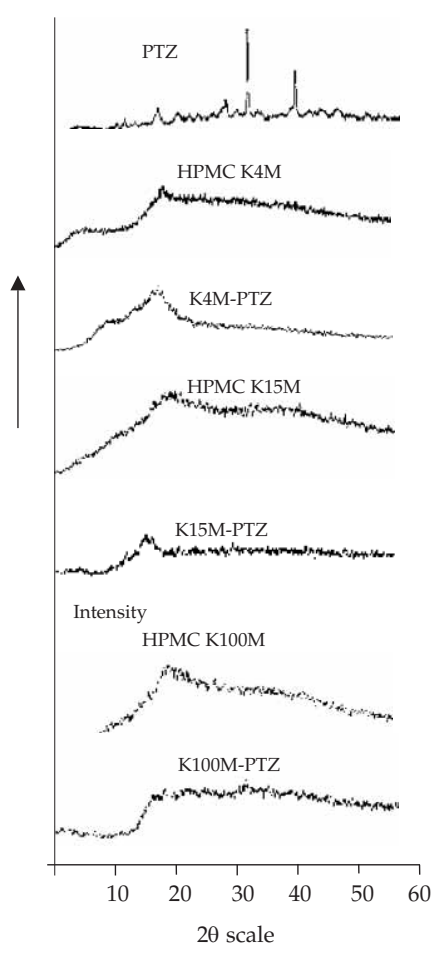

used. The drug release data were fitted for zero-order $\left(r_{0}\right)$, first-order $\left(r_{1}\right)$ and Higuchi-type $\left(r_{\mathrm{H}}\right)$ release kinetics. Release rates were calculated from the slope of per cent $\mathrm{cu}-$ mulative release $v s$. time $(t), \log$ per cent unreleased $v s$. time $(t)$ and per cent cumulative release $v s$. the square root of time $\left(t^{0.5}\right)$, respectively (Table II). The coefficient of correlation of each of these release kinetics was calculated and compared.

Irrespective of the HPMC grades, for the formulations containing a lower proportion of polymer, the release pattern was best fitted to the Higuchi kinetics equation since its coefficient of correlation $(R)$ predominates over zero-order and first order release kinetics. A significant linear correlation $(R=0.972-0.986, p<0.001)$ was found for the Higuchi-matrix release kinetics. In contrast, with an increase in polymer content in the matrix film, the zero order release pattern predominates over the first order and Higuchi-type release kinetics (Table II).

Furthermore, in order to better characterize the drug release behavior for polymeric matrix films, the Korsmeyer-Peppas semi empirical model was applied (19). From the statistical analysis of in vitro release data, the order of release was followed by anomalous, or non-Fickian, release mechanism, as the release exponent $(n)$ value falls between 0.5 and 1.0. In swellable systems, factors affecting release kinetics are the liquid diffusion rate and the polymeric chain relaxation rate. When the liquid diffusion rate is slower than the relaxation rate of the polymeric chains, the diffusion is Fickian whereas when the relaxation process is very slow compared to diffusion, the case II transport occurs. 
P. R. P. Verma and A. R. Chandak: Development of matrix controlled transdermal delivery systems of pentazocine: In vitro/in vivo performance, Acta Pharm. 59 (2009) 171-186.

Table II. Dissolution characteristics of pentazocine from transdermal films

\begin{tabular}{|c|c|c|c|c|c|c|c|c|}
\hline \multirow{2}{*}{$\begin{array}{l}\text { Formulation } \\
\qquad(m / m)\end{array}$} & \multicolumn{2}{|c|}{ Zero-order } & \multicolumn{2}{|c|}{ First-order } & \multicolumn{2}{|c|}{ Higuchi-matrix } & \multirow[b]{2}{*}{$n$} & \multirow{2}{*}{$t_{50}(\mathrm{~h})$} \\
\hline & $r_{0}\left(\mathrm{~mol} \mathrm{~L}^{-1} \mathrm{~h}^{-1}\right)$ & $\mathrm{R}$ & $r_{1}\left(\mathrm{~h}^{-1}\right)$ & $\mathrm{R}$ & $r_{\mathrm{H}}\left(\mathrm{h}^{-1 / 2}\right)$ & $\mathrm{R}$ & & \\
\hline \multicolumn{9}{|l|}{ PTZ:K4M } \\
\hline $1: 1$ & $\begin{array}{c}7.192 \\
(0.091)\end{array}$ & $\begin{array}{c}0.927 \\
(0.005)\end{array}$ & $\begin{array}{c}0.756 \\
(0.006)\end{array}$ & $\begin{array}{c}0.979 \\
(0.013)\end{array}$ & $\begin{array}{l}16.269 \\
(0.187)\end{array}$ & $\begin{array}{c}0.986 \\
(0.017)\end{array}$ & $\begin{array}{c}0.519 \\
(0.021)\end{array}$ & $\begin{array}{c}2.02 \\
(0.112)\end{array}$ \\
\hline $1: 1.5$ & $\begin{array}{c}7.176 \\
(0.086)\end{array}$ & $\begin{array}{c}0.942 \\
(0.004)\end{array}$ & $\begin{array}{c}0.644 \\
(0.009)\end{array}$ & $\begin{array}{c}0.962 \\
(0.008)\end{array}$ & $\begin{array}{l}16.174 \\
(0.156)\end{array}$ & $\begin{array}{c}0.981 \\
(0.022)\end{array}$ & $\begin{array}{c}0.519 \\
(0.018)\end{array}$ & $\begin{array}{c}2.55 \\
(0.221)\end{array}$ \\
\hline $1: 2$ & $\begin{array}{c}6.529 \\
(0.097)\end{array}$ & $\begin{array}{c}0.943 \\
(0.002)\end{array}$ & $\begin{array}{c}0.527 \\
(0.005)\end{array}$ & $\begin{array}{c}0.961 \\
(0.019)\end{array}$ & $\begin{array}{l}15.239 \\
(0.255)\end{array}$ & $\begin{array}{c}0.979 \\
(0.008)\end{array}$ & $\begin{array}{c}0.538 \\
(0.010)\end{array}$ & $\begin{array}{c}3.42 \\
(0.314)\end{array}$ \\
\hline $1: 2.5$ & $\begin{array}{c}6.215 \\
(0.107)\end{array}$ & $\begin{array}{c}0.945 \\
(0.004)\end{array}$ & $\begin{array}{c}0.416 \\
(0.008)\end{array}$ & $\begin{array}{c}0.943 \\
(0.016)\end{array}$ & $\begin{array}{l}14.912 \\
(0.145)\end{array}$ & $\begin{array}{c}0.974 \\
(0.016)\end{array}$ & $\begin{array}{c}0.561 \\
(0.015)\end{array}$ & $\begin{array}{c}4.03 \\
(0.224)\end{array}$ \\
\hline $1: 3$ & $\begin{array}{c}5.130 \\
(0.081)\end{array}$ & $\begin{array}{c}0.969 \\
(0.003)\end{array}$ & $\begin{array}{c}0.337 \\
(0.006)\end{array}$ & $\begin{array}{c}0.902 \\
(0.009)\end{array}$ & $\begin{array}{l}13.704 \\
(0.267)\end{array}$ & $\begin{array}{c}0.968 \\
(0.007)\end{array}$ & $\begin{array}{c}0.661 \\
(0.017)\end{array}$ & $\begin{array}{c}4.32 \\
(0.285)\end{array}$ \\
\hline $1: 3.5$ & $\begin{array}{c}4.397 \\
(0.061)\end{array}$ & $\begin{array}{c}0.982 \\
(0.005)\end{array}$ & $\begin{array}{c}0.233 \\
(0.012)\end{array}$ & $\begin{array}{c}0.873 \\
(0.015)\end{array}$ & $\begin{array}{l}12.199 \\
(0.098)\end{array}$ & $\begin{array}{c}0.965 \\
(0.009)\end{array}$ & $\begin{array}{c}0.711 \\
(0.014)\end{array}$ & $\begin{array}{c}5.11 \\
(0.264)\end{array}$ \\
\hline \multicolumn{9}{|l|}{ PTZ:K15M } \\
\hline $1: 1$ & $\begin{array}{c}6.225 \\
(0.093)\end{array}$ & $\begin{array}{c}0.940 \\
(0.012)\end{array}$ & $\begin{array}{c}0.673 \\
(0.008)\end{array}$ & $\begin{array}{c}0.969 \\
(0.014)\end{array}$ & $\begin{array}{l}14.944 \\
(0.266)\end{array}$ & $\begin{array}{c}0.982 \\
(0.018)\end{array}$ & $\begin{array}{c}0.573 \\
(0.018)\end{array}$ & $\begin{array}{c}2.51 \\
(0.213)\end{array}$ \\
\hline $1: 1.5$ & $\begin{array}{c}6.006 \\
(0.112)\end{array}$ & $\begin{array}{c}0.962 \\
(0.013)\end{array}$ & $\begin{array}{c}0.551 \\
(0.008)\end{array}$ & $\begin{array}{c}0.957 \\
(0.016)\end{array}$ & $\begin{array}{l}14.406 \\
(0.111)\end{array}$ & $\begin{array}{c}0.973 \\
(0.013)\end{array}$ & $\begin{array}{c}0.609 \\
(0.014)\end{array}$ & $\begin{array}{c}2.87 \\
(0.167)\end{array}$ \\
\hline $1: 2$ & $\begin{array}{c}5.299 \\
(0.058)\end{array}$ & $\begin{array}{c}0.972 \\
(0.009)\end{array}$ & $\begin{array}{c}0.424 \\
(0.009)\end{array}$ & $\begin{array}{c}0.926 \\
(0.012)\end{array}$ & $\begin{array}{l}13.311 \\
(0.334)\end{array}$ & $\begin{array}{c}0.974 \\
(0.016)\end{array}$ & $\begin{array}{c}0.611 \\
(0.015)\end{array}$ & $\begin{array}{c}3.85 \\
(0.164)\end{array}$ \\
\hline $1: 2.5$ & $\begin{array}{c}4.759 \\
(0.078)\end{array}$ & $\begin{array}{c}0.974 \\
(0.005)\end{array}$ & $\begin{array}{c}0.346 \\
(0.007)\end{array}$ & $\begin{array}{c}0.893 \\
(0.008)\end{array}$ & $\begin{array}{l}12.559 \\
(0.209)\end{array}$ & $\begin{array}{c}0.970 \\
(0.009)\end{array}$ & $\begin{array}{c}0.632 \\
(0.024)\end{array}$ & $\begin{array}{c}4.53 \\
(0.235)\end{array}$ \\
\hline $1: 3$ & $\begin{array}{c}4.319 \\
(0.103)\end{array}$ & $\begin{array}{c}0.982 \\
(0.004)\end{array}$ & $\begin{array}{c}0.225 \\
(0.005)\end{array}$ & $\begin{array}{c}0.868 \\
(0.006)\end{array}$ & $\begin{array}{l}11.860 \\
(0.254)\end{array}$ & $\begin{array}{c}0.964 \\
(0.014)\end{array}$ & $\begin{array}{c}0.757 \\
(0.018)\end{array}$ & $\begin{array}{c}5.23 \\
(0.211)\end{array}$ \\
\hline $1: 3.5$ & $\begin{array}{c}3.936 \\
(0.088)\end{array}$ & $\begin{array}{c}0.990 \\
(0.006)\end{array}$ & $\begin{array}{c}0.188 \\
(0.007)\end{array}$ & $\begin{array}{c}0.853 \\
(0.013)\end{array}$ & $\begin{array}{l}11.260 \\
(0.165)\end{array}$ & $\begin{array}{c}0.952 \\
(0.007)\end{array}$ & $\begin{array}{c}0.771 \\
(0.017)\end{array}$ & $\begin{array}{c}5.69 \\
(0.231)\end{array}$ \\
\hline \multicolumn{9}{|l|}{ PTZ:K100M } \\
\hline $1: 1$ & $\begin{array}{c}6.037 \\
(0.068)\end{array}$ & $\begin{array}{c}0.963 \\
(0.014)\end{array}$ & $\begin{array}{c}0.562 \\
(0.008)\end{array}$ & $\begin{array}{c}0.957 \\
(0.017)\end{array}$ & $\begin{array}{l}14.398 \\
(0.294)\end{array}$ & $\begin{array}{c}0.981 \\
(0.012)\end{array}$ & $\begin{array}{c}0.596 \\
(0.026)\end{array}$ & $\begin{array}{c}2.88 \\
(0.158)\end{array}$ \\
\hline $1: 1.5$ & $\begin{array}{c}5.365 \\
(0.073)\end{array}$ & $\begin{array}{c}0.967 \\
(0.018)\end{array}$ & $\begin{array}{c}0.451 \\
(0.007)\end{array}$ & $\begin{array}{c}0.933 \\
(0.008)\end{array}$ & $\begin{array}{l}13.516 \\
(0.241)\end{array}$ & $\begin{array}{c}0.972 \\
(0.012)\end{array}$ & $\begin{array}{c}0.622 \\
(0.024)\end{array}$ & $\begin{array}{c}3.20 \\
(0.222)\end{array}$ \\
\hline $1: 2$ & $\begin{array}{c}5.318 \\
(0.085)\end{array}$ & $\begin{array}{c}0.976 \\
(0.013)\end{array}$ & $\begin{array}{c}0.387 \\
(0.009)\end{array}$ & $\begin{array}{c}0.917 \\
(0.009)\end{array}$ & $\begin{array}{l}13.049 \\
(0.365)\end{array}$ & $\begin{array}{c}0.964 \\
(0.016)\end{array}$ & $\begin{array}{c}0.658 \\
(0.018)\end{array}$ & $\begin{array}{c}4.56 \\
(0.312)\end{array}$ \\
\hline $1: 2.5$ & $\begin{array}{c}4.390 \\
(0.059)\end{array}$ & $\begin{array}{c}0.981 \\
(0.009)\end{array}$ & $\begin{array}{c}0.313 \\
(0.011)\end{array}$ & $\begin{array}{c}0.887 \\
(0.016)\end{array}$ & $\begin{array}{l}12.156 \\
(0.188)\end{array}$ & $\begin{array}{c}0.952 \\
(0.013)\end{array}$ & $\begin{array}{c}0.652 \\
(0.022)\end{array}$ & $\begin{array}{c}5.11 \\
(0.244)\end{array}$ \\
\hline $1: 3$ & $\begin{array}{c}3.971 \\
(0.080)\end{array}$ & $\begin{array}{c}0.992 \\
(0.015)\end{array}$ & $\begin{array}{c}0.201 \\
(0.008)\end{array}$ & $\begin{array}{c}0.845 \\
(0.011)\end{array}$ & $\begin{array}{l}11.388 \\
(0.386)\end{array}$ & $\begin{array}{c}0.948 \\
(0.009)\end{array}$ & $\begin{array}{c}0.765 \\
(0.024)\end{array}$ & $\begin{array}{c}5.85 \\
(0.243)\end{array}$ \\
\hline $1: 3.5$ & $\begin{array}{c}3.197 \\
(0.077)\end{array}$ & $\begin{array}{c}0.998 \\
(0.008)\end{array}$ & $\begin{array}{c}0.178 \\
(0.006)\end{array}$ & $\begin{array}{c}0.841 \\
(0.015)\end{array}$ & $\begin{array}{r}9.880 \\
(0.154)\end{array}$ & $\begin{array}{c}0.921 \\
(0.011)\end{array}$ & $\begin{array}{c}0.861 \\
(0.016)\end{array}$ & $\begin{array}{c}6.48 \\
(0.266)\end{array}$ \\
\hline
\end{tabular}

Mean and standard deviation (in parentheses) $(n=3)$.

$r_{0}$ - zero-order; $r_{1}$ - first-order; and $r_{\mathrm{H}}$ - Higuchi-type dissolution rate constant; $n$ - Korsmeyer-Peppas release exponent. 
When the liquid diffusion rate and the polymer relaxation rate are of the same order of magnitude, anomalous or non-Fickian diffusion is observed (20). On the basis of these considerations, it is clear that the drug released from our formulations is controlled by liquid diffusion and polymeric chain relaxation. Reduction in release rate values with the increase in polymeric grades and content increases the time needed to release a given quantity of drug, allowing higher hydration and relaxation of the polymer matrix before release, which in turn shifts the release mechanism toward relaxation erosion.

Burst release was observed with all formulations, which could be attributed to the direct exposure of matrix films to dissolution media (Fig. 5). Fast release of the drug present at the surface occurs; this initial rapid release is attributed to the fact that the polymeric matrix may form loose channels within the network. This may be due to the hydrophilic nature of the polymer used. The observed initial release may help achieve the therapeutic plasma concentration of the drug in a short time along with a constant release rate for a longer period of time. Initial burst release was higher in matrix films formulated using a low viscosity grade polymer (HPMC K4M) compared to higher viscosity grade polymers (HPMC K15M and HPMC K100M). Due to initial burst effects, low dissolution half-life $\left(t_{50}\right)$ was found (Table II) in the case of matrix films formulated with HPMC K4M (2-5 h). The $t_{50}$ value increases while the dissolution rate constant (DRC) decreases linearly with an increase in concentration and viscosity grade of polymer (Figs. 6, 7).
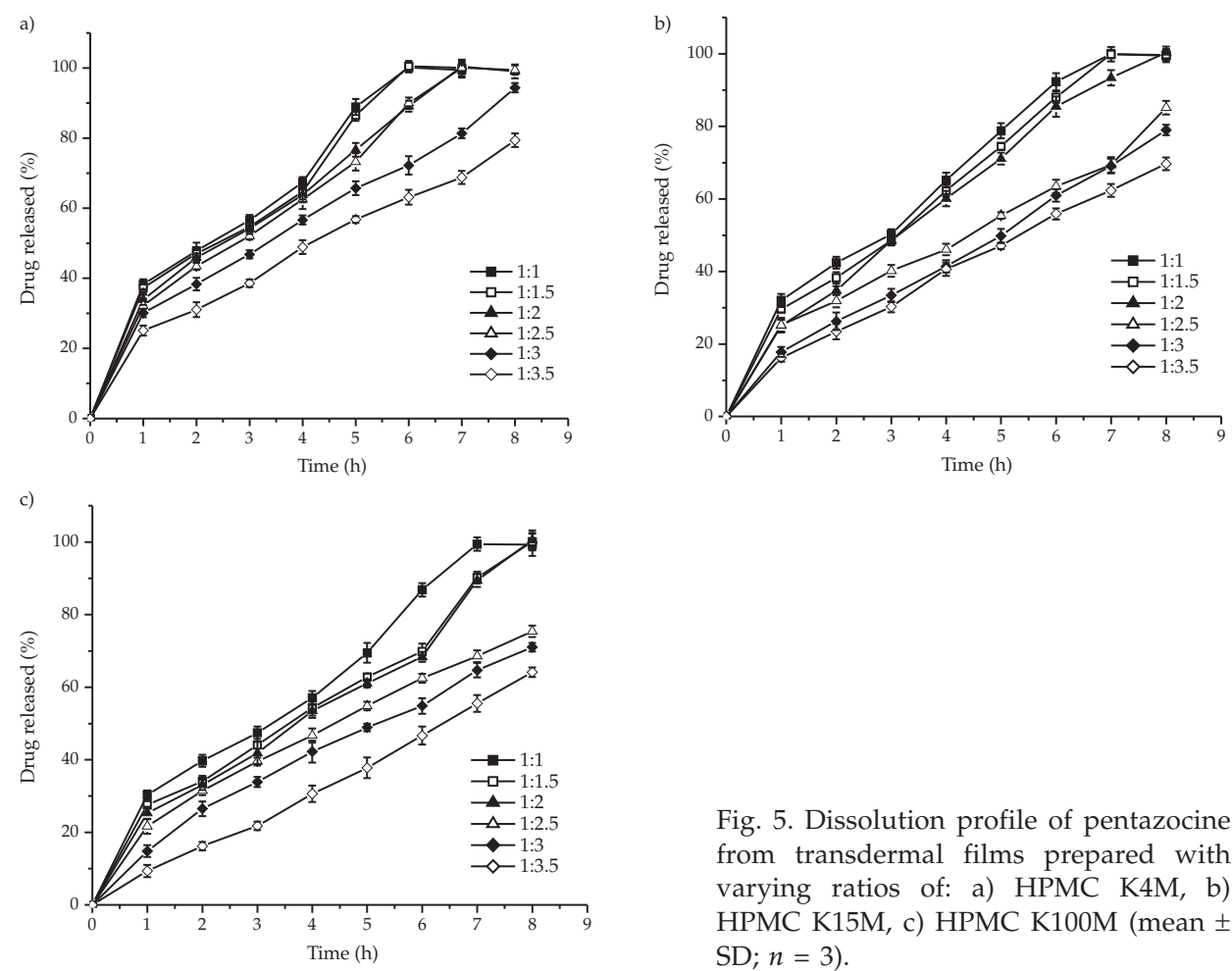

Fig. 5. Dissolution profile of pentazocine from transdermal films prepared with varying ratios of: a) HPMC $\mathrm{K} 4 \mathrm{M}, \mathrm{b}$ ) HPMC K15M, c) HPMC K100M (mean \pm $\mathrm{SD} ; n=3)$. 
P. R. P. Verma and A. R. Chandak: Development of matrix controlled transdermal delivery systems of pentazocine: In vitro/in vivo performance, Acta Pharm. 59 (2009) 171-186.

The relevance of the difference in $D R C$ and $t_{50}$ was evaluated statistically by two way ANOVA. The data show a significant difference between the test formulations $(p<$ 0.01 ) but not within the test formulations, indicating that test formulations differ significantly. Of the various formulations made using different concentrations and grades of HPMC, six formulations (A-F) were selected on the basis of the drug content and release pattern. The release patterns of the selected formulations were best suited for Higuchi kinetics, with a significant linear correlation $(R=0.968-0.981, p<0.001$, Table II) indicating slow and controlled drug release, thus supporting the selected formulation suitable for transdermal films (11).

\section{In vivo studies in rabbits}

On the basis of physicochemical characterization and in vitro release profile, six formulations (A-F) were selected for comparative in vivo studies (Table III). The skin irritation study indicated that neither the polymer nor the drug caused any noticeable edema, erythema or inflammation in or around the patch area either during the period of study or after patch removal.
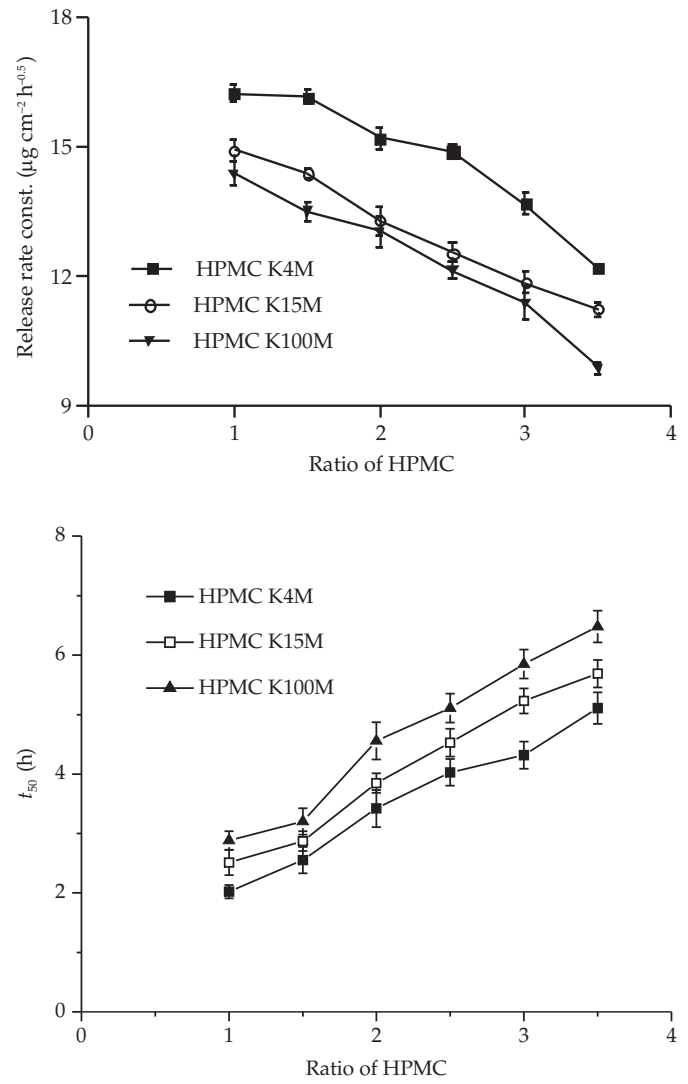

Fig. 6. Release rate constant vs. HPMC ratios in matrix transdermal films of pentazocine (mean $\pm \mathrm{SD} ; n=3$ ).
Fig. 7. Dissolution half life vs. HPMC ratios in matrix transdermal films of pentazocine (mean $\pm \mathrm{SD} ; n=3$ ). 
P. R. P. Verma and A. R. Chandak: Development of matrix controlled transdermal delivery systems of pentazocine: In vitro/in vivo performance, Acta Pharm. 59 (2009) 171-186.

Fig. 8. Blood concentration-time profile of pentazocine after applying transdermal patches in rabbits (mean $\pm \mathrm{SD} ; n=3$ ).

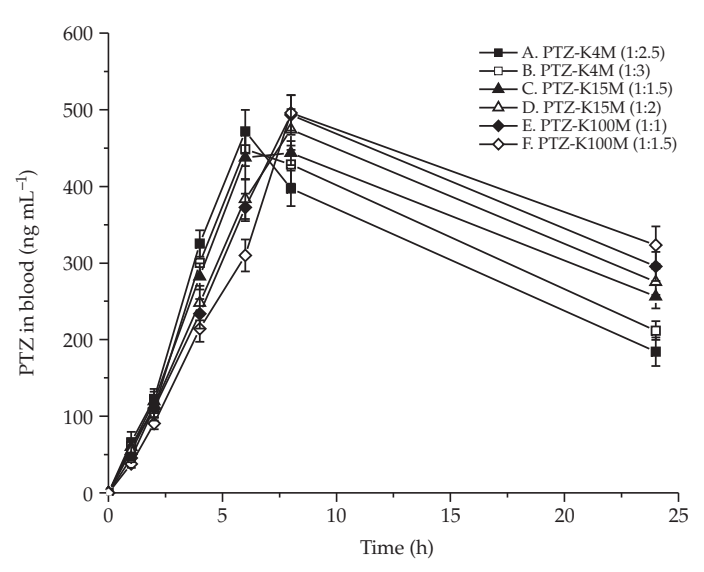

For the comparative bioavailability study, blood data of all test products were considered. Pharmacokinetic parameters $C_{\max }, t_{\max }, A U C_{(\mathrm{s})}, t_{1 / 2}, K_{\mathrm{el}}$, and $M R T$ data are shown in Table III. The mean blood concentration $v s$. time profiles of all six test products (A-F) are depicted in Fig. 8. On the basis of $A U C_{(0-24)}, A U C_{(0-\infty)}, M R T$ and $t_{1 / 2}$ values, the selected products A-F could be ranked as follows: $\mathrm{F}>\mathrm{E}>\mathrm{D}>\mathrm{C}>\mathrm{B}>\mathrm{A}$ (Table III). The calculated parameters indicate that the biological half-life $\left(t_{1 / 2}\right)$ of PTZ was prolonged from $2-4 \mathrm{~h}$ (reported data) to $18.96 \pm 3.65 \mathrm{~h}$ (transdermal) in rabbits. Hence, the drug administered through a transdermal patch will remain longer in the body and thus exert a sustained action. The significantly lower elimination rate constant $0.038 \pm 0.008 \mathrm{~h}^{-1}$ and

Table III. Mean pharmacokinetic parameters of pentazocine after administration of transdermal films to rabbits

\begin{tabular}{|c|c|c|c|c|c|c|c|c|c|}
\hline Code & Formulation & $\begin{array}{l}t_{\max } \\
(\mathrm{h})\end{array}$ & $\begin{array}{c}C_{\max } \\
\left(\text { ng mL } L^{-1}\right)\end{array}$ & $\begin{array}{r}t_{1 / 2} \\
(\mathrm{~h})\end{array}$ & $\begin{array}{l}K_{\mathrm{el}} \\
\left(\mathrm{h}^{-1}\right)\end{array}$ & $\begin{array}{c}A U C_{0-12} \\
\left(\mathrm{~h} \mathrm{ng} \mathrm{mL} \mathrm{mL}^{-1}\right)\end{array}$ & $\begin{array}{c}A U C_{0-24} \\
\left(\mathrm{~h} \mathrm{ng} \mathrm{mL}^{-1}\right)\end{array}$ & $\begin{array}{c}A U C_{0-\infty} \\
\left(\mathrm{h} \mathrm{ng} \mathrm{mL} \mathrm{mL}^{-1}\right)\end{array}$ & $\begin{array}{c}\text { MRT } \\
\text { (h) }\end{array}$ \\
\hline & PTZ:K4M & & & & & & & & \\
\hline A & 1:2.5 & 6 & $\begin{array}{c}451.85 \\
(4.6)\end{array}$ & $\begin{array}{l}14.09 \\
(12.1)\end{array}$ & $\begin{array}{l}0.049 \\
(12.1)\end{array}$ & $\begin{array}{c}3685.15 \\
(2.8)\end{array}$ & $\begin{array}{c}6854.94 \\
(4.2)\end{array}$ & $\begin{array}{c}10686.56 \\
\quad(5.6)\end{array}$ & $\begin{array}{l}10.56 \\
(1.4)\end{array}$ \\
\hline \multirow[t]{2}{*}{ B } & $1: 3$ & 6 & $\begin{array}{c}458.43 \\
(4.7)\end{array}$ & $\begin{array}{l}16.01 \\
(13.7)\end{array}$ & $\begin{array}{l}0.043 \\
(19.0)\end{array}$ & $\begin{array}{c}3597.02 \\
(2.2)\end{array}$ & $\begin{array}{c}6925.83 \\
(5.6)\end{array}$ & $\begin{array}{c}12510.46 \\
(10.8)\end{array}$ & $\begin{array}{l}11.08 \\
(2.5)\end{array}$ \\
\hline & PTZ:K15M & & & & & & & & \\
\hline C & 1:1.5 & 6 & $\begin{array}{c}480.60 \\
(3.0)\end{array}$ & $\begin{array}{r}17.41 \\
(9.9)\end{array}$ & $\begin{array}{r}0.040 \\
(9.4)\end{array}$ & $\begin{array}{c}3570.67 \\
(4.0)\end{array}$ & $\begin{array}{c}7868.94 \\
(1.6)\end{array}$ & $\begin{array}{c}14624.96 \\
(8.6)\end{array}$ & $\begin{array}{l}11.39 \\
(1.2)\end{array}$ \\
\hline \multirow[t]{2}{*}{$\mathrm{D}$} & $1: 2$ & 8 & $\begin{array}{c}464.30 \\
(5.5)\end{array}$ & $\begin{array}{l}21.04 \\
(11.7)\end{array}$ & $\begin{array}{l}0.033 \\
(22.5)\end{array}$ & $\begin{array}{c}3513.66 \\
(3.5)\end{array}$ & $\begin{array}{c}8054.86 \\
(2.5)\end{array}$ & $\begin{array}{c}16665.33 \\
(14.1)\end{array}$ & $\begin{array}{l}11.86 \\
(2.6)\end{array}$ \\
\hline & PTZ:K100M & & & & & & & & \\
\hline E & $1: 1$ & 8 & $\begin{array}{c}493.33 \\
(3.2)\end{array}$ & $\begin{array}{l}21.87 \\
(12.0)\end{array}$ & $\begin{array}{l}0.032 \\
(11.5)\end{array}$ & $\begin{array}{c}3491.95 \\
(5.6)\end{array}$ & $\begin{array}{c}8229.47 \\
(2.4)\end{array}$ & $\begin{array}{c}17472.26 \\
(12.5)\end{array}$ & $\begin{array}{l}12.03 \\
(1.4)\end{array}$ \\
\hline $\mathrm{F}$ & 1:1.5 & 8 & $\begin{array}{c}495.95 \\
(2.7)\end{array}$ & $\begin{array}{r}23.31 \\
(3.9)\end{array}$ & $\begin{array}{r}0.029 \\
(3.8)\end{array}$ & $\begin{array}{c}3418.46 \\
(2.5)\end{array}$ & $\begin{array}{c}8327.09 \\
(2.2)\end{array}$ & $\begin{array}{c}21337.05 \\
(11.7)\end{array}$ & $\begin{array}{l}12.59 \\
(3.4)\end{array}$ \\
\hline
\end{tabular}

Mean and per cent RSD (in parentheses) $(n=3)$. 


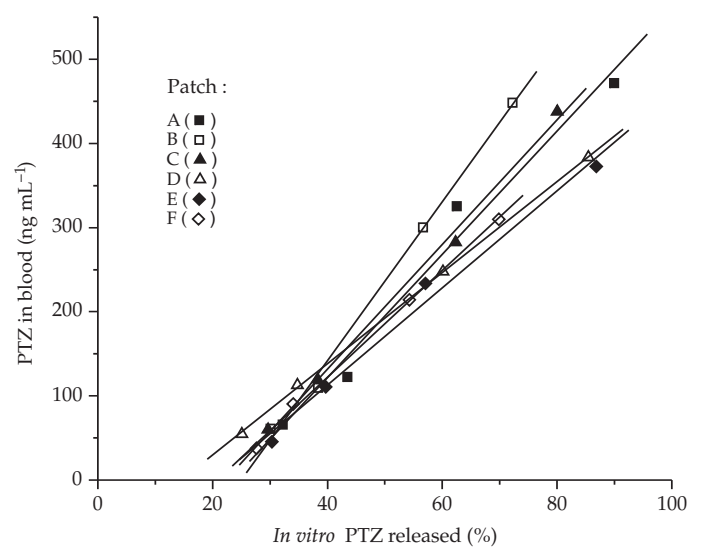

Fig. 9. In vitro per cent drug released from selected matrix transdermal films and blood concentration of pentazocine at the same time points.

high mean residence time values $11.58 \pm 0.73 \mathrm{~h}$ of PTZ further support sustained action of the drug from transdermal patches. The high AUC values observed with the patches also indicate increased bioavailability of the drug. This may be due to the bypass of hepatic first-pass effects. These results are in agreement with the findings reported earlier $(21,22)$.

Upon statistical evaluation (two-way ANOVA), a significant difference was observed between the test products $(p<0.01)$ but not within the test products for $A U C_{(0-12)}$, $A U C_{(0-24)}, A U C_{(0-\infty)}, t_{1 / 2}, K_{\mathrm{el}}$ and $M R T$ values. Spearman rank correlation, a non-parametric statistical test, demonstrated a high degree of positive correlation, showing complete agreement in the order of ranks between the percentage of drug absorbed from patches and $C_{\max }\left(p<0.02\right.$; two tails), $A U C_{(0-24)}\left(p<0.02\right.$; two tails) and $A U C_{(0-\infty)}(p<$ 0.02; two tails). The increase in the amount of drug absorbed was thus associated with the increase in blood level and area under the plasma concentration curve (extent of absorption). This was further quantitatively confirmed by regression analysis, showing good correlation between the percentage of drug absorbed and $C_{\max }(R=0.965, p<0.01)$, $A U C_{(0-24)}(R=0.863, p<0.05)$ and $A U C_{(0-\infty)}(R=0.918, p<0.01)$.

A significant in vitro/in vivo correlation was observed when per cent drug released from the products was correlated with A-F blood drug concentration obtained at the same time. The linearity of those plots was well supported by the coefficient of corelation which ranged from 0.989 to 0.999 and significant linear correlation $(p<0.01)$.

\section{CONCLUSIONS}

The results of this study indicate that polymeric grades of HPMC used have an excellent film forming ability. The polymeric-matrix type transdermal films of pentazocine prepared with different grades and ratios of HPMC were found good in psysicochemical, in vitro dissolution and pharmacokinetic characteristics, and thus have a potential for transdermal delivery. A slow and controlled release of the drug is indicated by the fact that the per cent cumulative amount of drug released vs. square root of time is found to 
P. R. P. Verma and A. R. Chandak: Development of matrix controlled transdermal delivery systems of pentazocine: In vitro/in vivo performance, Acta Pharm. 59 (2009) 171-186.

be linear, thus supporting that these products are suitable for transdermal films. Further, the selected formulations, which have been screened, may be evaluated for their pharmacokinetic profiles in humans by optimizing the drug loading and size of transdermal patches.

Acknowledgements. - The authors thank Vice-Chancellor, Birla Institute of Technology, Mesra for providing the necessary facilities. The helpful discussion of Mrs. S. M. Verma is acknowledged. One of the authors (A. R. Chandak) gratefully acknowledges financial support in the form of Senior Research Fellowship provided during the period of study by the University Grants Commission, New Delhi, India.

\section{REFERENCES}

1. J. W. Wiechers, The barrier functions of the skin in relation to percutaneous absorption of drugs, Pharm. Weekbl. 11 (1989) 185-198.

2. D. C. Monkhouse and A. S. Huq, Transdermal drug delivery - problems and promises, Drug Dev. Ind. Pharm. 14 (1988) 183-203.

3. M. B. Brown, G. P. Martin, S. A. Jones and F. K. Akomeah, Dermal and transdermal drug delivery systems: Current and future prospects, Drug Del. 13 (2006) 175-187; DOI: 10.1080/ 10717540500455975.

4. B. T. Kurihara, W. R. Good, S. Feusullin and C. Signor, Skin compatibility of transdermal drug delivery system, J. Control. Rel. 15 (1991) 271-278; DOI: 10.1016/0168-3659(91)90119-X.

5. T. Furuishi, S. Oda, H. Saito, T. Fukami, T. Suzuki and K. Tomono, Effect of permeation enhancers on the in vitro percutaneous absorption of pentazocine, Biol. Pharm. Bull. 30 (2007) 1350- 1353.

6. V. Agarwal and B. Mishra, Design, development, and biopharmaceutical properties of buccoadhesive compacts of pentazocine, Drug Dev. Ind. Pharm. 25 (1999) 701-709; DOI: 10.1081/DDC100102229.

7. M. Bhattacharyya, S. C. Mandal, B. Sa and B. K. Gupta, Studies on controlled release formulations of pentazocine hydrochloride, Drug Dev. Ind. Pharm. 20 (1994) 1613-1629; DOI: 10.3109/ 03639049409050202.

8. C. Valenta and B. G. Auner, The use of polymers for dermal and transdermal delivery, Eur. J. Pharm. Biopharm. 58 (2004) 279-289; DOI: 10.1016/j.ejpb.2004.02.017.

9. United States Pharmacopoeia 25, National Formulary 20, USP Convention, Rockville 2002, pp. 2018.

10. P. R. P. Verma and S. S. Iyer, Transdermal delivery of propranolol using mixed grades of eudragit: design and in vitro and in vivo evaluation, Drug Dev. Ind. Pharm. 26 (2000) 471-476; DOI: 10.1081/DDC-100101257.

11. A. R. Chandak and P. R. P. Verma, Development and evaluation of HPMC based matrices for transdermal patches of tramadol, Clin. Res. Reg. Affairs 25 (2008) 13-30; DOI: 10.1080/10601330701885066.

12. M. Man, C. Chang, P. H. Lee, C. T. Broman and G. W. Cleary, New improved paddle method for determining the in vitro drug release profiles of transdermal delivery systems, Control. Rel. 27 (1993) 59-68; DOI: 10.1016/0168-3659(93)90057-C.

13. B. Berkowitz and E. L. Way, Metabolism and excretion of pentazocine in man, Clin. Pharmacol. Ther. 10 (1969) 681-689.

14. Clarke's Isolation and Identification of Drugs in Pharmaceuticals, Body Fluids, and Post-mortem Materials, (Ed. A. C. Moffat), $2^{\text {nd }}$ ed., Pharmaceutical Press, London 1986, pp. 860-861. 
P. R. P. Verma and A. R. Chandak: Development of matrix controlled transdermal delivery systems of pentazocine: In vitro/in vivo performance, Acta Pharm. 59 (2009) 171-186.

15. S. Wartewig and R. H. H. Neubert, Pharmaceutical applications of Mid-IR and Raman spectroscopy, Adv. Drug Del. Rev. 57 (2005) 1144-1170; DOI: 10.1016/j.addr.2005.01.022.

16. T. D. Wilson, Pentazocine, in Analytical Profiles of Drug Substance (Ed. K. Florey), Vol. 13, Pharmaceutical Press, London 1984, pp. 361-416.

17. R. K. Verma and S. Garg, Compatibility studies between isosorbide mononitrate and selected excipients used in the development of extended release formulations, J. Pharm. Biomed. Anal. 35 (2004) 449-458; DOI:10.1016/j.jpba.2004.01.012.

18. R. C. Mundargi, S. A. Patil, S. A. Agnihotri and T. M. Aminabhavi, Evaluation and controlled release characteristics of modified xanthan films for transdermal delivery of atenolol, Drug Dev. Ind. Pharm. 33 (2007) 79-90; DOI: 10.1080/03639040600975030.

19. R. W. Korsmeyer, R. Gurny, E. Doelker, P. Buri and N. A. Peppas, Mechanism of solute release from porous hydrophilic polymers, Int. J. Pharm. 15 (1983) 25-35; DOI: 10.1016/0378-5173(83) 90064-9.

20. L. Perioli, V. Ambrogi, D. Rubini, S. Giovagnoli, M. Ricci, P. Blasi and C. Rossi, Novel mucoadhesive buccal formulation containing metronidazole for the treatment of periodontal disease, J. Control. Rel. 95 (2004) 521-533; DOI: 10.1016/j.jconrel.2003.12.018.

21. S. Mutalik and N. Udupa, Glibenclamide transdermal patches: Physicochemical, pharmacodynamic, and pharmacokinetic evaluations, J. Pharm. Sci. 93 (2004) 1577-1594; DOI: 10.1002/jps. 20058.

22. U. D. Rohr, R. Altenburger and T. Kissel, Pharmacokinetics of the transdermal reservoir membrane system delivering $\beta$-estradiol: in vitro/in vivo correlation, Pharm. Res. 15 (1998) 877-882.

\section{$S A \check{Z} E T A K$}

\section{Razvoj matriksnih sustava za transdermalnu isporuku pentazocina: In vitro/in vivo ispitivanje}

PRIYA RANJAN PRASAD VERMA i ASHOK R. CHANDAK

U radu je opisan razvoj transdermalnih sustava na bazi hidroksipropil metilceluloze za isporuku pentazocina. U pripravcima koji sadrže manje udjele polimera, otpuštanje lijeka slijedilo je Higuchijevu kinetiku. Međutim, ako je udio polimera veći oslobađanje je najbolje odgovaralo kinetici nultog reda. Vrijednost eksponenta $n$ implicira da oslobađanje pentazocina iz matriksa nije po Fickovom zakonu. FT-IR, DSC i XRD studije ukazuju da nema interakcije između ljekovite tvari i polimera. In vitro konstanta oslobađanja, poluvrijeme oslobađanja i farmakokinetički parametri $\left(C_{\max }, t_{\max }, \operatorname{AUC}_{(\mathrm{s})}, t_{1 / 2}\right.$, $\left.K_{\mathrm{el}}, \mathrm{i} M R T\right)$ procijenjeni su statistički koristeći ANOVA program. Značajna razlika primijećena je između, ali ne i unutar testiranih pripravaka. Pronađena je dobra korelacija između lijeka apsorbiranog iz flastera i $C_{\max }$ i $A U C_{(s)}$ te oslobođenog lijeka i koncentracije lijeka u krvi. Rezultati ukazuju da su polimerni matriksni filmovi pentazocina potencijalno dobri sustavi za transdermalnu primjenu lijeka.

Ključne riječi: pentazocin, transdermalna isporuka lijekova, Cygnusov držač flastera, in vitro karakterizacija, in vivo vrednovanje

Department of Pharmaceutical Sciences, Birla Institute of Technology, Mesra, Ranchi-835215, India 